\title{
Reduction of Sound Distortion for a Magnetic Circuit in a Loudspeaker Based on Finite Element Analysis
}

\author{
Yasuhiro Shiraki Member (Mitsubishi Electric Corporation, Shiraki.Yasuhiro@db.MitsubishiElectric.co.jp) \\ Mikio Watanabe Non-member (Mitsubishi Electric Corporation, Watanabe.Mikio@dp.MitsubishiElectric.co.jp) \\ Masashi Okabe Member (Mitsubishi Electric Corporation, Okabe.Masashi@ce.MitsubishiElectric.co.jp) \\ Shiro Koga Non-member (Mitsubishi Electric Corporation, Koga.Shiro@dh.MitsubishiElectric.co.jp)
}

Keywords : finite element analysis, loudspeaker, magnetic circuit, incremental permeability, sound distortion

\section{Introduction}

Reduction of a sound distortion in loudspeakers has been required for high performance audio systems. The sound distortion induced by a drive system is caused by AC flux density generated by the voice coil current. It is known that the distortion is reduced by digging a hole at the upper surface of the pole piece. However there are few reports on the optimization of the pole piece for reducing the distortion. Using a finite element method and an experimental method, we have studied the optimization of the pole piece for reducing the distortion. We developed prototypes of loudspeaker, and measured the $2^{\text {nd }}$ harmonics of their sound distortion.

\section{Analysis Model and Analysis Method}

The structure of a speaker unit is shown in Fig. 1. We investigated the AC flux density by the voice coil current which effects on the 2nd harmonic of the distortion. Figure 1 and Table 1 shows shape and dimension of the pole piece respectively.

$\mathrm{AC}$ flux density $|\mathrm{Bg}|$ at the voice coil is calculated as follows.

[step1] Calculation of DC flux density distribution in magnetic materials by a nonlinear static magnetic field analysis.

[step2] Experiments to obtain the incremental relative permeability corresponding to DC flux density.

[step3] Calculation of $|\mathrm{Bg}|$ by a linear dynamic magnetic field analysis using the obtained incremental relative permeability.

\section{Results}

Calculation results of $\mathrm{AC}$ flux density $|\mathrm{Bg}|$ at 50, 100 and $200 \mathrm{~Hz}$ are shown in Table 2. When the position of pole piece top is heightened as model 2 , it is found that that $|\mathrm{Bg}|$ become lower than that of model 1 . When the pole piece has a hole as model 3

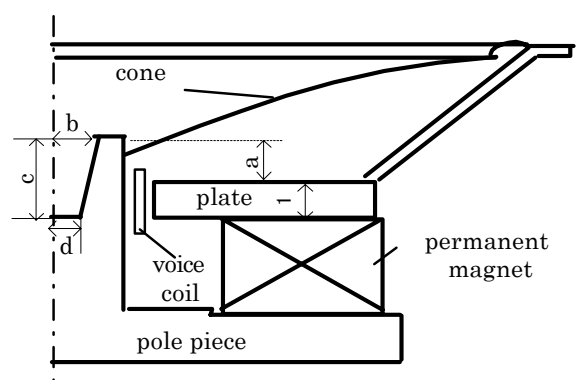

Fig. 1. Cross section of loudspeaker unit through model $6,|\mathrm{Bg}|$ become lower than those of the others. Model 6, whose hole bottom is located lower than the plate, is superior to the others.

Table 3 shows the measurement results of the 2nd harmonic of the sound distortions. When $|\mathrm{Bg}|$ is low, the 2nd harmonics become low.

Table 1. Dimension of pole piece

\begin{tabular}{c|c|c|c|c|c}
\hline & \multirow{2}{*}{$\begin{array}{c}\text { pole piece } \\
\text { shape }\end{array}$} & \multicolumn{4}{|c}{$\begin{array}{c}\text { dimension of pole piece } \\
\text { (arbitary unit) }\end{array}$} \\
\cline { 3 - 6 } & & $\mathrm{a}$ & $\mathrm{b}$ & $\mathrm{c}$ & $\mathrm{d}$ \\
\hline model 1 & without hole & 0.16 & - & - & - \\
\hline model 2 & without hole & 0.67 & - & - & - \\
\hline model 3 & with hole & 0.67 & 2.00 & 1.67 & 1.44 \\
\hline model 4 & with hole & 0.67 & 1.56 & 1.67 & 1.44 \\
\hline model 5 & with hole & 0.67 & 2.00 & 1.44 & 1.56 \\
\hline model 6 & with hole & 0.67 & 1.56 & 2.11 & 1.44 \\
\hline model 7 & with hole & 0.44 & 1.64 & 1.89 & 1.44 \\
\hline model 8 & with hole & 0.16 & 1.60 & 1.60 & 1.44 \\
\hline
\end{tabular}

Table 2. AC magnetic flux density $|\mathrm{Bg}|\left(\times 10^{-4} \mathrm{~T}\right)$

\begin{tabular}{c|c|c|c}
\hline model & $50 \mathrm{~Hz}$ & $100 \mathrm{~Hz}$ & $150 \mathrm{~Hz}$ \\
\hline model 1 & 75 & 62 & 48 \\
\hline model 2 & 61 & 49 & 36 \\
\hline model 3 & 60 & 48 & 35 \\
\hline model 4 & 60 & 48 & 35 \\
\hline model 5 & 60 & 48 & 35 \\
\hline model 6 & 58 & 46 & 33 \\
\hline model 7 & - & 53 & - \\
\hline model 8 & - & 60 & - \\
\hline
\end{tabular}

Table 3. 2nd harmonic in the sound distortion (dB)

\begin{tabular}{c|c|l|l}
\hline model & $50 \mathrm{~Hz}$ & $100 \mathrm{~Hz}$ & $150 \mathrm{~Hz}$ \\
\hline model 1 & -24 & -31 & -42 \\
\hline model 2 & -25 & -33 & -46 \\
\hline model 3 & -25 & -35 & -48 \\
\hline model 6 & -25 & -36 & -50
\end{tabular}




\title{
論 文 \\ 有限要素法に基づくスピーカ磁気回路の音圧ひずみ低減
}

\author{
正員 白木 康博* 非会員 渡辺 幹男** \\ 正 員 岡部 正志* 非会員 古賀 士朗***
}

\section{Reduction of Sound Distortion for a Magnetic Circuit in a Loudspeaker Based on Finite Element Analysis}

\author{
Yasuhiro Shiraki*, Member, Mikio Watanabe**, Non-member, Masashi Okabe*, Member,
}

Shiro Koga***, Non-member

\begin{abstract}
A new magnetic circuit for a low distortion loudspeaker has been studied using a finite element analysis considering a minor hysteresis loop. The magnetic materials in the vicinity of the voice coil are magnetized by fields both AC currents and a permanent magnet. A minor hysteresis loop is induced by this magnetization. The incremental permeability of minor hysteresis loop effects on the sound distortion. We calculated the flux distribution of the magnetic circuit using a finite element method, considering the incremental permeability of the minor hysteresis loop obtained by an experimental method. It is clarified the relation between the sound distortion caused by the flux distribution and the magnetic structure. The developed magnetic circuit has a pole piece which has a hole at the upper surface and which is located higher than the plate.
\end{abstract}

キーワード : 有限要素法, スピーカ, 磁気回路, 増分透磁率, 音圧ひずみ, マイナーループ

Keywords : finite element analysis, loudspeaker, magnetic circuit, incremental permeability, sound distortion, minor loop

\section{1. まえがき}

オーディオ機器の性能向上のために，スピーカ音圧ひず みの低減が要求されている。音圧ひずみの発生系は振動系 と駆動系に大別されるが，本論文では駆動系に起因するひ ずみ（以下，駆動ひずみ）に関する解析方法とその検討結 果について述べる。駆動系は永久磁石と磁性ヨークから構 成される直流磁気回路の空隙部にコーンに直結されたボイ スコイルを配置して，交流信号電流（以下，ボイスコイル 電流）を印加させることにより駆動する構造となっている(1)。 駆動系に起因するひずみとして，(1)ボイスコイル部が置か れた空隙部（以下，ボイスコイル部）における直流磁束密 度の不均一が影響する駆動ひずみ，(2)ボイスコイル電流に

\footnotetext{
* 三菱電機(株) 先端技術総合研究所

干 661-8661 尼崎市塚口本町 8-1-1

Advanced Technology R\&D Center, Mitsubishi Electric Corp.

8-1-1, Tsukaguchi-honmachi, Amagasaki 661-8661

** 三菱電機(株) 群馬製作所

干370-0403 太田市岩松町 800

Gunma Works, Mitsubishi Electric Corp.

800 Iwamatucho, Oota 370-0403

*** 三菱電機(株) モバイルターミナル製作所

产661-8661 尼崎市塚口本町 8-1-1

Mobile Terminal Works, Mitsubishi Electric Corp.,

8-1-1, Tsukaguchi-honmachi, Amagasaki 661-8661
}

より磁化される磁性体のヒステリシス性に基づくボイスコ イル電流の波形ひずみ，(3)゙イスコイル電流から発生する 交流磁束による駆動ひずみ，等がある(1) (4)。

駆動ひずみを低減させる方法として，ボイスコイル近傍 の磁性体に積層した方向性けい素鋼板を用いて, 交流磁束 の通る方向の磁気抵抗を増加させること ${ }^{(1)}$, ボイスコイル近 傍の磁性体に銅製のショートリングを付加して，うず電流 による交流磁束の打ち消し効果を利用すること(1)(2),(4), 動作 時の磁束密度で直流的に十分飽和する低飽和磁束密度部材 を使い，マイナーループの線形化をはかること(1)，ボイスコ イル近傍のポールピースに切れ込みを入れる方法(1)などが よくおこなわれる。このうち，ポールピースに切れ込みを 入れる方法は, コスト低減と軽量化の点で他の方法よりも 有利である。ポールピースに切れ込みを入れると, ボイス コイル近傍の磁性体が飽和状態となり，交流信号に対しヒ ステリシス曲線を直線化かつ傾きを小さくして, 交流磁束 の発生とボイスコイル電流の波形ひずみを防ぐことができ る。

駆動系の磁気回路設計のうち，ボイスコイル部の直流磁 束密度の不均一分布およびボイスコイル電流から発生する 交流磁束による駆動ひずみについて, 有限要素法を用いた 検討がおこわれている(2)(3)。しかし, 文献( 2 )では交流磁束 
による駆動ひずみを低減するために有限要素法を用いてい るが，交流磁束を非磁性体のうず電流で減少させることを 目的としており, 直流磁束密度に対応して変化する増分透 磁率を考慮していない。増分透磁率を考慮して, 平滑チョ ークコイルを有限要素解析する方法が文献(5)に示されて いる。しかし, 増分比透磁率の測定では LCR メタを用い ているのでマイナーループのヒステリシス性を考慮してい ない。

本論文では，ボイスコイル電流から発生する交流磁束に よる駆動ひずみを低減する磁気回路構造について検討し た。そのために, 直流磁束密度に応じたマイナーループを 測定し増分透磁率やヒステリシス性を検討した(6)。さらに, これらの増分透磁率特性を有限要素解析に反映させてスピ 一力磁気回路の最適化をおこなった(6)。

第 2 章では振動板がコーン形で磁気回路の外周部にフェ ライト磁石を配置したスピーカの構造を示す。また, 駆動 系の音圧ひずみの要因について述べる。

第 3 章ではボイスコイル部の直流磁束密度を検討する。 磁気回路構造として, ボイスコイル近傍のポールピース上 部の切れ込み形状とポールピース高さを検討する。文献(6) では，ポールピース高さ一定条件下で，切れ込み形状につ いての検討がおこなわれている。本論文ではポールピース の高さを変えた場合の最適な切れ込み形状について検討す る。有限要素法を用いた非線形静磁界解析を用いて, ボイ スコイル部の直流磁束密度を計算して，実測值と比較する。

第 4 章では音圧ひずみに影響を与える交流磁束の検討を おこなう。まず，直流磁束に重畳した交流磁束のマイナー ループを測定する。次に有限要素法を用いて, 有限要素毎 にマイナーループの増分透磁率を与えて，ボイスコイル部 の交流磁束密度を解析し, 最適な磁気回路形状を検討する。 最後に駆動ひずみを最も低減できる磁気回路を用いたスピ 一カを試作して，音圧ひずみを検討する。

\section{2. スピーカの構造および駆動系に起因する音圧 ひずみの検討}

図 1 に示すように，本論文で検討をおこなう振動板がコ ーン形で, 磁気回路の外周部に永久磁石（フェライト磁石） を配置した外磁形のものである。そして，永久磁石，プレ ートおよびポールピースから成る磁気回路部分，およびボ イスコイルの振動を音にするためのコーン，ダンパおよび フレームから成る振動部分で構成されている。

ボイスコイル電流によって発生する交流磁束が駆動力 F に及ぼす影響について述べる。ボイスコイルの駆動力 F は (1)式で表される。

$$
\mathrm{F}=\mathrm{Bg} \cdot \mathrm{d} \cdot \mathrm{i}
$$

ここで, Bg はボイスコイルに鎖交する半径方向の磁束密 度， i はボイスコイルに流れる電流， d はボイスコイルの 有効長である。

ボイスコイルに鎖交する半径方向の磁束密度 B g は, 図 2

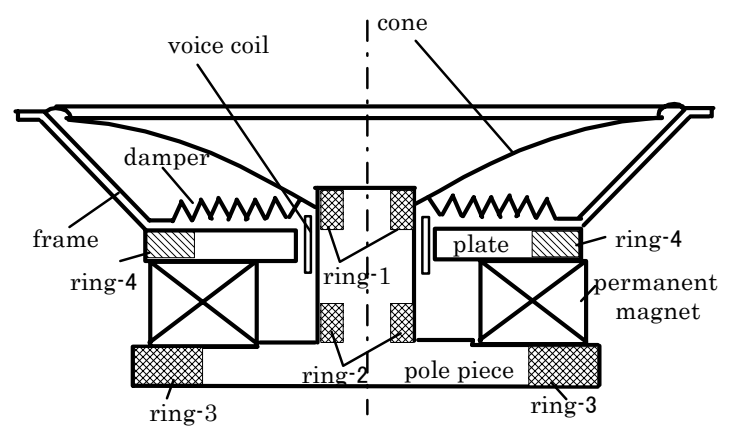

図1 スピーカの構造

Fig. 1. Cross section of loudspeaker unit.

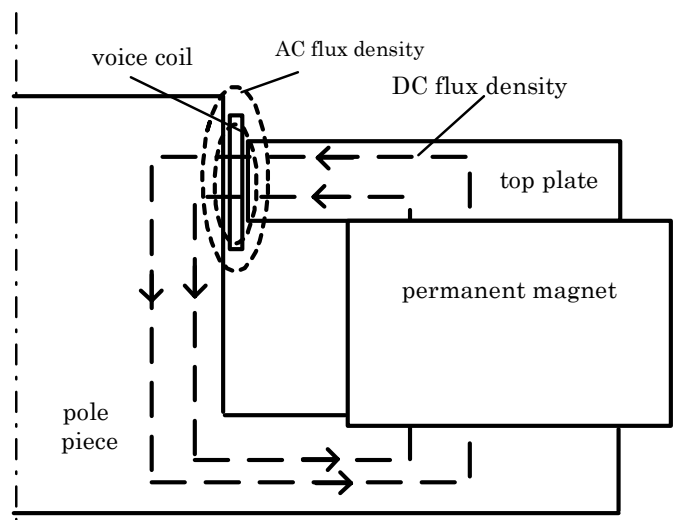

図 2 スピーカ磁気回路の磁束分布

Fig. 2. Flux distribution of loudspeaker unit.

に示すように永久磁石から発生する直流磁束密度 BgDC に, ボイスコイル電流によって発生する交流磁束密度が重畳す るので，次式で表される。

$$
\mathrm{Bg}=\mathrm{Bg}_{\mathrm{DC}}+|\Delta \mathrm{Bg}| \sin (\omega \mathrm{t}+\alpha)
$$

ただし, | $\Delta \mathrm{Bg} \mid$ はボイスコイルに鎖交する半径方向の交 流磁束密度の振幅, $\alpha$ は電流と交流磁束密度の位相角であ る。

一方, ボイスコイル電流を正弦波とすると, 次式で表さ れる。

$$
\mathrm{i}=\mathrm{im} \cdot \sin (\omega \mathrm{t})
$$

(2)および( 3 )式を(1)式に代入し, 変形すると(4)式が得 られる。

$$
\begin{aligned}
\mathrm{F}= & \mathrm{Bg}_{\mathrm{DC}}\{\mathrm{d} \cdot \mathrm{im} \cdot \sin (\omega \mathrm{t}) \\
& +0.5 \cdot\left(|\Delta \mathrm{Bg}| / \mathrm{Bg}_{\mathrm{DC}}\right) \cdot \mathrm{d} \cdot \mathrm{im} \cdot \cos (\alpha) \\
& \left.-0.5 \cdot\left(|\Delta \mathrm{Bg}| / \mathrm{Bg}_{\mathrm{DC}}\right) \cdot \mathrm{d} \cdot \mathrm{im} \cdot \cos (2 \omega \mathrm{t}+\alpha)\right\}
\end{aligned}
$$

(4)式の第 2 項はボイスコイルの振動中心が移動する原因 となり，第 3 項は二次ひずみの一因となる。

第 2 項および第 3 項のひずみは, $|\Delta \mathrm{Bg}|$ に比例し, $\mathrm{Bg}_{\mathrm{DC}}$ に反比例するために, 本論文では $|\Delta \mathrm{Bg}| / \mathrm{Bg}_{\mathrm{DC}}$ を低減する 磁気回路について有限要素法を用いて検討する。 


\section{3. ボイスコイル部の直流磁束密度分布}

〈3.1〉 ポールピース形状ポールピースに切れ込み を入れると, ボイスコイル部の直流磁束密度 $\mathrm{Bg}_{\mathrm{DC}}$ が低下す ることや不均一になることが考えられる。そこで, 有限要 素法を用いた軸対称非線形静磁界解析をおこない，ボイス コイル部の直流磁束分布を検討した。

図 3 および表 1 にポールピースの形状を変えた 8 種類の スピーカ磁気回路を示寸。なお, 表 1 に示す寸法はプレー トの高さを 1 とした相対值として示す。

モデル選定では，ポールピース部の加工コストおよび強 度面を考慮するとともに, 切り込みなしに比べてボイスコ イル部の直流磁束密度の低下割合が少なくなるようなモデ ルを中心に選定した。モデル 1 と 2 はポールピースの上部 を平面にして，プレート上面に対するポールピースの高さ を変えた場合である。モデル $3 \sim 8$ はポールピース上部に切 れ込みを入れた場合である。モデル $3,4,6,7$ および 8 で はプレート下面と同一高さのポールピース部の断面積をプ レート内径部の表面積と同一にして，プレート下面と同一 高さのポールピース部の直流磁束密度とプレート部の直流 磁束密度が同一になるようにした。モデル 3 および 4 はプ レート下面とポールピース切れ込みの下面を同一高さとし て，切れ込み角度を変えた場合である。モデル 5 および 6 はそれぞれモデル 3 および 4 の切れ込み深さを変えた場合

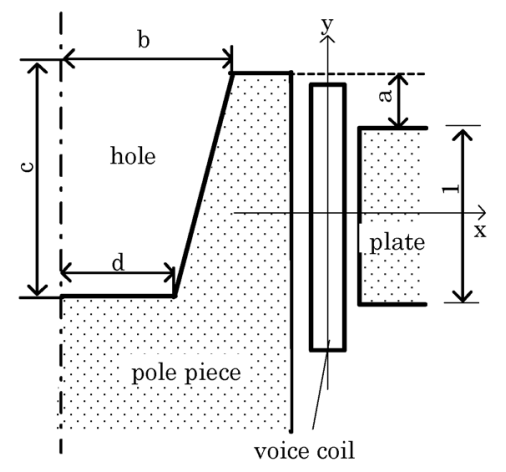

図 3 ポールピース形状

Fig. 3. Pole piece shape.

表 1 ポールピース寸法

Table 1. Dimension of pole piece.

\begin{tabular}{c|c|c|c|c|c}
\hline & \multirow{2}{*}{$\begin{array}{c}\text { pole piece } \\
\text { shape }\end{array}$} & \multicolumn{4}{|c}{$\begin{array}{c}\text { dimension of pole piece } \\
\text { (arbitary unit) }\end{array}$} \\
\cline { 3 - 6 } & & $\mathrm{a}$ & $\mathrm{b}$ & $\mathrm{c}$ & $\mathrm{d}$ \\
\hline model 1 & without hole & 0.16 & - & - & - \\
\hline model 2 & without hole & 0.67 & - & - & - \\
\hline model 3 & with hole & 0.67 & 2.00 & 1.67 & 1.44 \\
\hline model 4 & with hole & 0.67 & 1.56 & 1.67 & 1.44 \\
\hline model 5 & with hole & 0.67 & 2.00 & 1.44 & 1.56 \\
\hline model 6 & with hole & 0.67 & 1.56 & 2.11 & 1.44 \\
\hline model 7 & with hole & 0.44 & 1.64 & 1.89 & 1.44 \\
\hline model 8 & with hole & 0.16 & 1.60 & 1.60 & 1.44 \\
\hline
\end{tabular}

である。モデル 7 および 8 はポールピースの高さをモデル 6 に比べて低くした場合である。

〈3·2〉磁性体の初磁化曲線の実測 ポールピースと プレートの材質はそれぞれ機械構造用炭素鋼と熱間圧延軟 鋼である。ポールピースとプレートの磁気特性は加工時の 応力によって変化する。そこで, 図 1 に示すポールピース 部 3 箇所, プレート部 1 箇所をリング上に加工して, 初磁 化曲線を実測した。図 4 に磁性体の初磁化曲線を示す。プ レート材の RING-4 の透磁率が最も高く, 以下ポールピー ス材の RING-2，RING-1，RING-3 の順になる。

$\langle 3 \cdot 3\rangle$ 静磁界解析と実測を用いた直流磁束密度の検討

プレート部を RING-4, ポールピースの初磁化曲線を最も 透磁率の低い RING-3 として, 表 1 に示す 8 種類のポール ピース形状について, 有限要素法を用いて軸対称三次元で 非線形静磁界解析をおこなった。

表 2 にボイスコイル部の磁束密度分布の最大值とボイス コイル部の平均磁束密度に関する解析結果を示す。図 5 に 図 3 に示す $\mathrm{y}$ 軸上の直流磁束密度分布を示す。表 2 よりポ ールピースの切れ込みの有無に関係なく, モデル $2 \sim 6$ のよ うにポールピースをプレート上面より高くすると, モデル 1， 7 および 8 に比べて直流磁束密度がやや低下寸るがその 低下度合いは $4 \%$ 以内である。また，モデル 3〜 6 のように ポールピースの高さが同じであれば，切れ込みの形状に関 係なく直流磁束密度はほぼ同じである。図 5 に示すように 直流磁束密度の解析結果と実測結果はほぼ一致する。

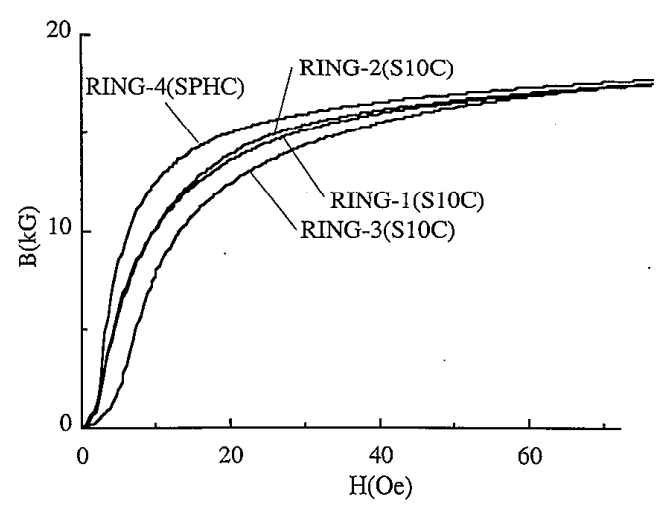

図 4 初磁化曲線

Fig. 4. Initial magnetization curve.

表 2 ボイスコイル部の直流磁束密度

Table 2. DC flux density at the voice coil portion.

\begin{tabular}{c|c|c}
\hline \multirow{2}{*}{ model } & \multicolumn{2}{|c}{ DC flux density $(\mathrm{T})$} \\
\cline { 2 - 3 } & maximum & average \\
\hline model1 & 1.020 & 0.778 \\
\hline model2 & 0.976 & 0.758 \\
\hline model3 & 0.974 & 0.756 \\
\hline model4 & 0.974 & 0.756 \\
\hline model5 & 0.975 & 0.757 \\
\hline model6 & 0.970 & 0.753 \\
\hline model7 & 0.984 & 0.768 \\
\hline model8 & 1.020 & 0.774 \\
\hline
\end{tabular}




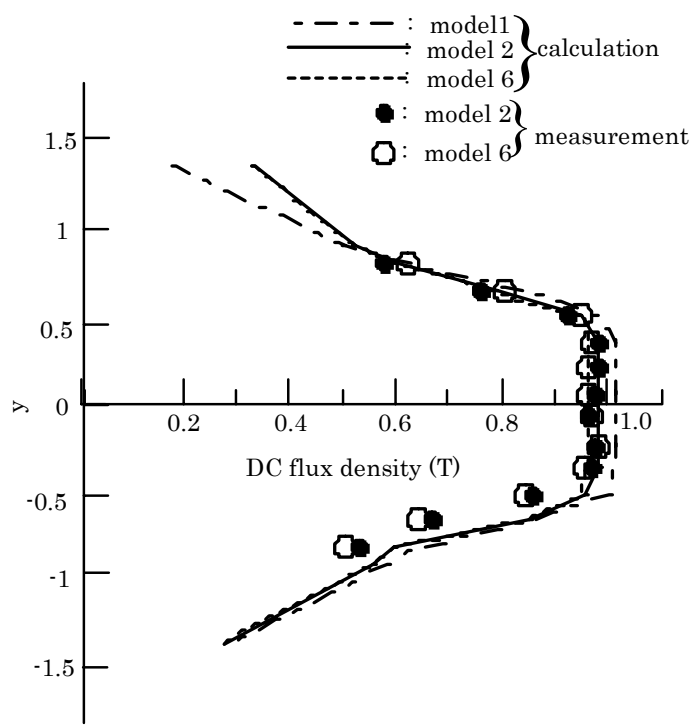

図 5 ボイスコイル部の直流磁束密度の 実測と解析結果

Fig. 5. DC flux distribution at the voice coil portion.

このように, 直流磁束密度の大きさはポールピースの高 さに影響され，ポールピース上部に切れ込みを入れる場合， プレート下面と同一高さのポールピースの断面積をプレー 卜内径部の表面積より大きくすれば，切れ込みの形状変化 はボイスコイル部の直流磁束密度の大きさには影響を及ぼ さない。

\section{4. ボイスコイル部の交流磁束分布}

〈4·1〉 マイナーループの測定ボイスコイル近傍の 磁性体には，永久磁石で発生する直流磁界による直流磁束 と，ボイスコイル電流に比例した交流磁界による交流磁束 が重畳する。この交流磁界と交流磁束が描く軌跡はマイナ ーループを形成する。さらにポールピース部の形状により 直流磁束密度が変化して, それに伴ってマイナーループが 変化する。そのため, ボイスコイル電流によって発生する 交流磁束の影響を磁界解析するためには，直流磁束密度に 応じたマイナーループの特性が必要となる。

そこで，図 6 に示すような測定装置を用いて $60 \mathrm{~Hz}$ のマ イナーループを実測した。一次巻線，三次巻線にはそれぞ れ直流磁束密度に対応するメジャーループ，交流磁束密度 に対応するマイナーループを測定するための励磁電流を流 す。二次巻線メジャーループとマイナーループに相当する 出力電圧が重畳して誘起されるが，交流結合の差動入力付 増幅器を用いることにより，マイナーループを測定できる。

図 7 にポールピース材とプレート材のマイナーループの 実測結果を示す。直流磁束密度が高くなるほど，磁性体の 増分比透磁率, マイナーループのヒステリシス性は小さく なる。今回の検討対象であるポールピースのヒステリシス 性は設計上の直流磁束密度である $1.2 \mathrm{~T}$ を超えると，ほとん ど無視することができる。図 8 に直流磁束密度と増分比透 磁率の関係を示す。ただし, 増分比透磁率 $\Delta \mu$ は次式で定

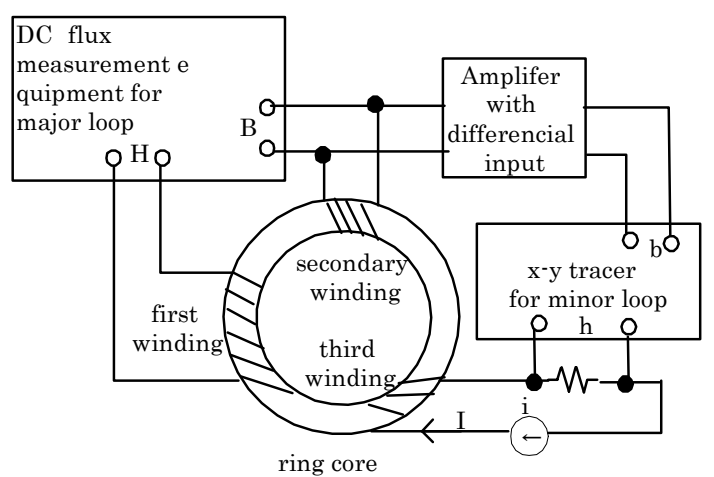

図 6 マイナーループ測定装置

Fig. 6. Measurement equipment for minor loops.

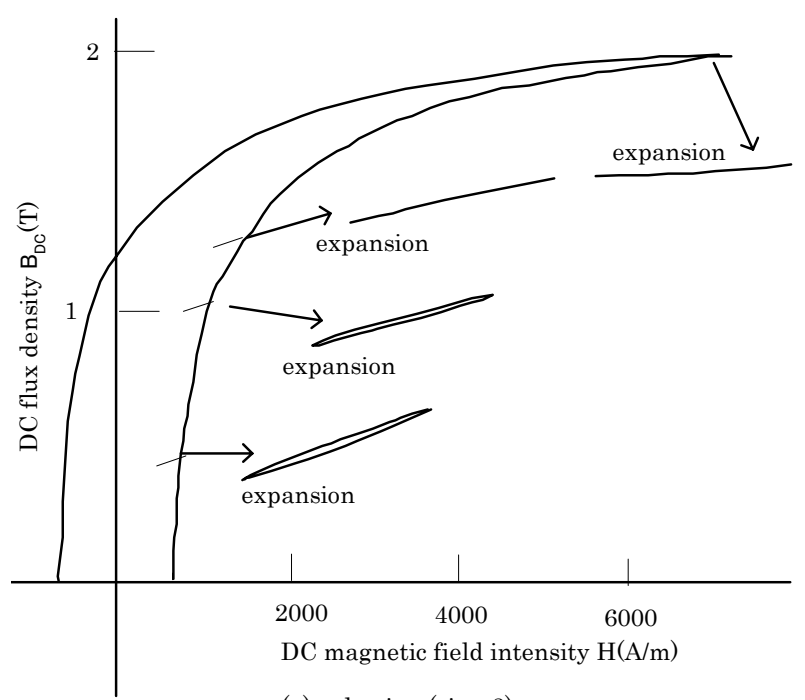

(a) pole piece(ring-3)

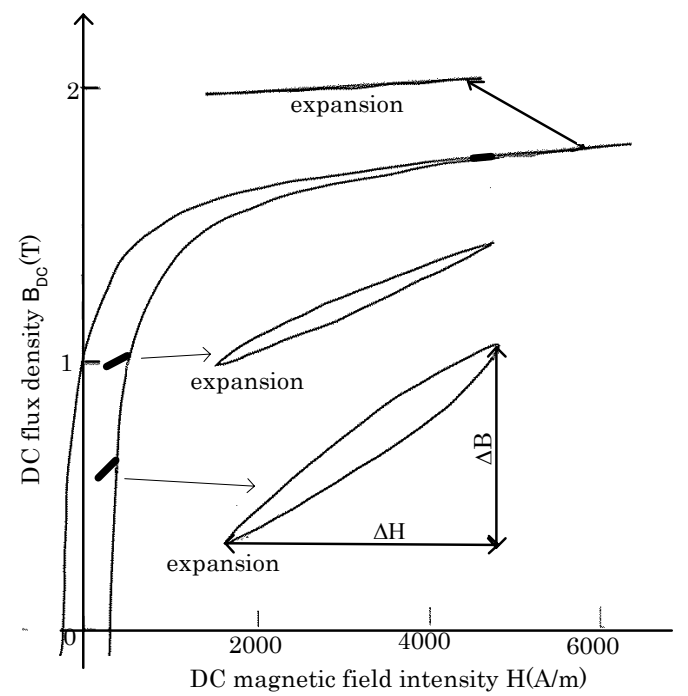

(b) plate(ring-4)

図 7 マイナーループの測定結果

Fig. 7. Measurements of minor loops. 


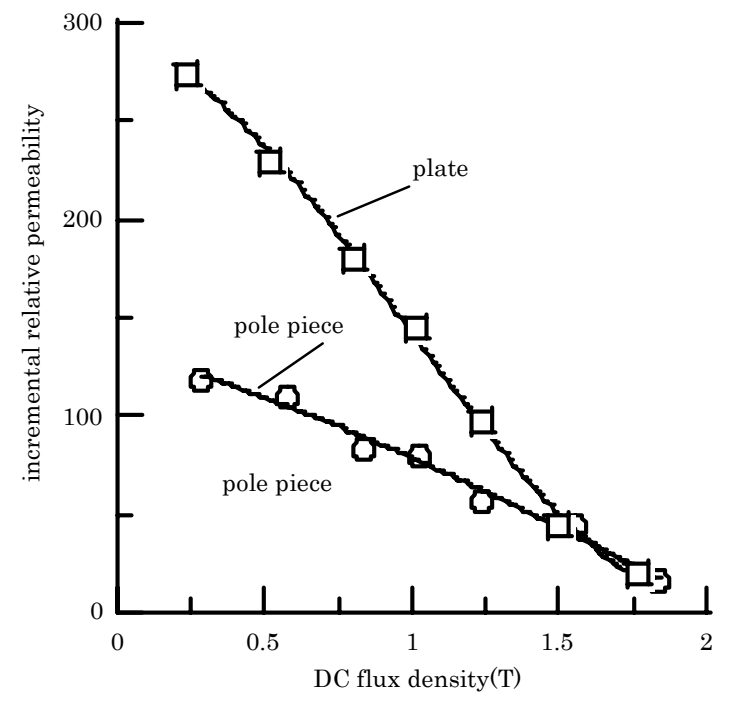

図 8 磁性体の直流磁束密度と増分比透磁率の関係

Fig. 8. Relation between incremental relative permeability and DC flux density.

義した。

$$
\Delta \mu=\Delta \mathrm{B} /(\mu \mathrm{o} \cdot \Delta \mathrm{H})
$$

ただし， $\Delta \mathrm{B}$ は交流磁束密度の最大変化量 $(\mathrm{T}), \Delta \mathrm{H}$ は交 流磁界の最大変化量 $(\mathrm{A} / \mathrm{m}), \mu \mathrm{o}$ は真空の透磁率とした。図 8 より, 直流磁束密度が等しい場合, プレート材の増分比透 磁率はポールピース材より大きいことがわかる。

〈4·2〉 スピーカ動作時の交流磁束の磁界解析 磁性 体の増分比透磁率は $\langle 3 \cdot 3\rangle$ 節で計算した磁性体の直流磁束 密度に応じた図 8 の増分比透磁率とし，有限要素毎に与え た。なお，マイナーループのヒステリシス性は前章で検討 したように，最適形状を検討するポールピースでは直流磁 束密度が $1.2 \mathrm{~T}$ 以上ではほぼ零であるので，無視した。ポー ルピースおよびプレートの導電率は $8.0 \times 10^{6}(\mathrm{~S} / \mathrm{m})$ とした。 永久磁石の比透磁率は 1 とした。直流抵抗が $1.6 \Omega$ のボイス コイルに $1.4 \mathrm{~V}$ の交流電圧を印加して，その周波数を 50 , $100,200 \mathrm{~Hz}$ と変えて, 有限要素法を用いて軸対称三次元で 交流線形計算をおこなった。解析モデルは図 3 および表 1 に示す 8 種類のポールピース形状とした。

表 3 にボイスコイル部の交流磁束密度の振幅 $|\mathrm{Bg}|$ の計算 結果を示す。表 4 にポールピース表面の交流磁束密度の振 幅 | Bg2 | の計算結果を示す。モデル 1 をモデル 2 のように ポールピースをプレート上面より高くすると, 表 4 に示す ポイント 1 と 2 で|Bg2|の差異が少なくなる。そのため, 互いに位相が逆であるボイスコイル上部と下部の交流磁束 が打ち消し合うことから，表 3 に示寸 $|\mathrm{Bg}|$ が小さくなる。 ポールピース高さが高いモデル $3 \sim 6$ では, モデル 6 のよう に切り込み深さをプレート下面より深くすると, さらにポ イント 1 と 2 で|Bg2|の差異が少なくなる。また, モデル 6 ではポイント 3 および 4 で| $\mathrm{Bg} 2 \mid$ が最も小さくなり, 交流 磁束が磁性体に浸入できにくくなるために交流磁束の発生
表 3 ボイスコイル部の交流磁束密度の振幅

$|\mathrm{Bg}|$ の解析結果

Table 3. Maximum value of AC magnetic flux density, $|\mathrm{Bg}|$, at the voice coil portion.

\begin{tabular}{c|c|c|c|c|c|c}
\hline \multirow{2}{*}{ model } & \multicolumn{2}{|c|}{$50 \mathrm{~Hz}$} & \multicolumn{2}{c|}{$100 \mathrm{~Hz}$} & \multicolumn{2}{c}{$150 \mathrm{~Hz}$} \\
\cline { 2 - 7 } & $\begin{array}{c}|\mathrm{Bg}| \\
\left(\times 10^{-4} \mathrm{~T}\right)\end{array}$ & $\begin{array}{c}|\mathrm{Bg}| \\
/ \mathrm{Bg}_{\mathrm{DC}}\end{array}$ & $\begin{array}{c}|\mathrm{Bg}| \\
\left(\times 10^{-4} \mathrm{~T}\right)\end{array}$ & $\begin{array}{c}|\mathrm{Bg}| \\
/ \mathrm{Bg}_{\mathrm{DC}}\end{array}$ & $\begin{array}{c}|\mathrm{Bg}| \\
\left(\times 10^{-4} \mathrm{~T}\right)\end{array}$ & $\begin{array}{c}|\mathrm{Bg}| \\
/ \mathrm{Bg}_{\mathrm{DC}}\end{array}$ \\
\hline model 1 & 75 & 0.0096 & 62 & 0.0080 & 48 & 0.0062 \\
\hline model 2 & 61 & 0.0081 & 49 & 0.0065 & 36 & 0.0047 \\
\hline model 3 & 60 & 0.0079 & 48 & 0.0063 & 35 & 0.0046 \\
\hline model 4 & 60 & 0.0079 & 48 & 0.0063 & 35 & 0.0046 \\
\hline model 5 & 60 & 0.0079 & 48 & 0.0063 & 35 & 0.0046 \\
\hline model 6 & 58 & 0.0077 & 46 & 0.0061 & 33 & 0.0044 \\
\hline model 7 & - & - & 53 & 0.0069 & - & - \\
\hline model 8 & - & - & 60 & 0.0075 & - & - \\
\hline
\end{tabular}

表 4 ポールピース表面の交流磁束密度の振幅 $|\mathrm{Bg} 2|$ の解析結果

Table 4. Maximum value of AC magnetic flux density, | $\mathrm{Bg} 2 \mid$, on the surface of pole piece.

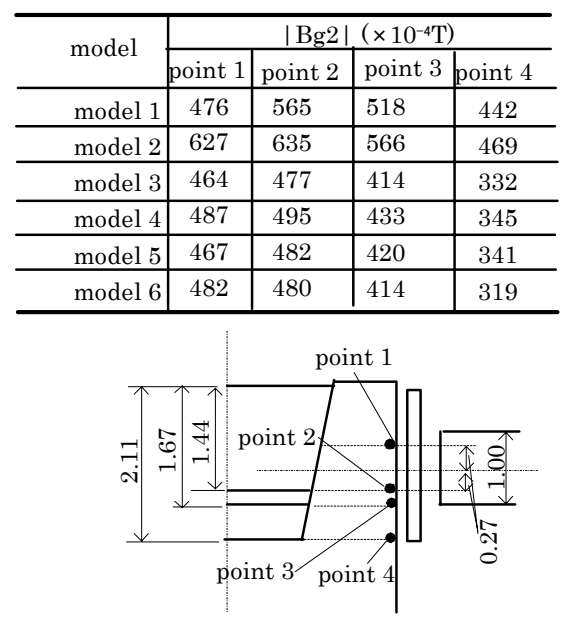

量自体が減少する。よって, モデル 6 では表 3 に示す $|\mathrm{Bg}|$ が最も小さくなる。また, モデル 6 は直流磁束密度に対す る交流磁束密度 $|\mathrm{Bg}| / \mathrm{Bg}_{\mathrm{DC}}$ も最小となり, モデル 1 に比べ て, $50 \mathrm{~Hz}$ で約 $20 \%$ 改善できる。また, モデル 6 で切れ込 み形状において, ポールピース高さを変えたモデル 7 およ び 8 では, 直流磁束密度に対する交流磁束密度 $|\mathrm{Bg}| / \mathrm{Bg}_{\mathrm{DC}}$ がモデル 6 より大きくなり, 駆動ひずみが増加する。これ らの傾向は周波数に関係なく, ほぼ同じである。

以上の結果より，ポールピースの高さをプレート上面よ り高くして, ポールピースの切れ込み深さをプレート下面 より深くした磁気回路が最も交流磁束による駆動ひずみを 低減することがわかった。

〈4·3〉音圧ひずみの実測前節で示した磁界解析結 果を検証するために, 4 種類のポールピース形状を試作し て, 音圧ひずみを実測した。表 5 に周波数が $50,100,200 \mathrm{~Hz}$ の音圧ひずみの実測結果を示す。モデル 2 のようにポール ピースをプレート上面より高くすると, モデル 1 に比べて 音圧ひずみは低減する。さらに, モデル 5 および 6 のよう 
表 5 高調波音圧ひずみの 2 次および 3 次成分

Table 5. 2nd and 3rd harmonic in the sound distortion.

\begin{tabular}{c|c|l|l|l|l|l}
\hline \multirow{2}{*}{ model } & \multicolumn{3}{|c|}{ 2nd harmonic (dB) } & \multicolumn{3}{c}{ 3rd harmonic (dB) } \\
\cline { 2 - 7 } & $50 \mathrm{~Hz}$ & $100 \mathrm{~Hz}$ & $150 \mathrm{~Hz}$ & $50 \mathrm{~Hz}$ & $100 \mathrm{~Hz}$ & $150 \mathrm{~Hz}$ \\
\hline model 1 & -24 & -31 & -42 & -17 & -31 & -52 \\
\hline model 2 & -25 & -33 & -46 & -18 & -32 & -53 \\
\hline model 5 & -25 & -35 & -48 & -18 & -32 & -53 \\
\hline model 6 & -25 & -36 & -50 & -18 & -33 & -54 \\
\hline
\end{tabular}

にポールピースに切れ込みを入れると，モデル 2 より音圧 ひずみを小さくできる。また，モデル 6 のようにポールピ 一スの切れ込みを深くするとモデル 5 より音圧ひずみを小 さくできる。これらの傾向は周波数に関係なくほぼ同じで あり，二次ひずみの低減効果が三次ひずみより大きい。こ のように直流磁束密度に対して, 最もボイスコイル部の交 流磁束密度が小さいモデル 6 がモデル 1 に比べて, 最大 $8 \mathrm{~dB}$

$(200 \mathrm{~Hz}$ の二次ひずタ) 改善でき, ポールピースの高さお よび切り込みに関する最適形状であることがわかった。

\section{5. まとめ}

本論文では，スピーカの音圧ひずみ低減のために磁性体 のマイナーループの増分透磁率特性を有限要素解析に反映 させて，スピーカ磁気回路の交流磁束密度分布を計算する 手法を確立した。さらに，本手法を用いて，音圧ひずみを 低減するスピーカ磁気回路の最適設計ができることを示 し，スピーカ磁気回路に関する設計上の知見が得られたの で以下に示す。

（1） ポールピースをプレート上面より高くして，ポール ピースの切れ込み深さをプレート下面より深くすると，ボ イスコイル電流から発生する交流磁束による駆動ひずみを 低減することができ，音圧ひずみが低減する。

（2） ポールピース高さをプレート上面より高くすると， ボイスコイル部の直流磁束密度は低下寸るが, 直流磁束密 度に対する交流磁束密度が低減するので, 音圧ひずみを低 減できる。

（3）ポールピース上面に切れ込みを入れる場合には，プ レートと同一高さのポールピースの断面積をプレート内径 の表面積より大きくすれば，ボイスコイル部の直流磁束密 度には影響を及ぼすことなく, 交流磁束密度を低減できる。

(平成 17 年 7 月 22 日受付, 平成 17 年 10 月 21 日再受付)

\section{文献}

（1）佐伯多門 : スピーカ\&エンクロージャー百科, 正文堂新光社（1981）

(2) T. Omura, M. Okabe, M. Okumura, and M. Yajima : "A High-Quality Speaker System”, Mitsubishi Denki Giho, Vol.63, No.10, pp.853-857 (1989-10) (in Japanese)
大村俊次・岡部正志・奥村正富 :「高性能スピーカーシステム」, 三 菱電機技報, 63, No.10, pp.853-857 (1989-10)

(3) H. Tsuchiya, M. Okada, H. Ikeda, T. Nomura, and T. Saeki : "The Reduction of Nonlinear Distortion Due to the Driving Mechanism in Loudspeakers", Mitsubishi Denki Giho, Vol.50, No.12, pp.670-674 (1976-12) (in Japanese) 土屋英司・岡田 将・池田英男・野村達衛・佐伯多門 :「スピーカの 駆動系による非直線ひずみの低減」，三菱電機技報，50，No.12， pp.670-674 (1976-12)

(4) H. Tsuchiya, M. Okada, H. Ikeda, T. Nomura, and T. Saeki : The Role of the FN Ring in the Development of a Low-Distortion

（5）平野芳生・岩田圭司・佐藤 駿:「直流重畳特性の計算方法」, 平成 4 年電気学会全国大会, No.1656 (1992)

（6）白木康博・渡辺幹男・岡部正志・古賀士朗 :「ポールピースの最適設 計によるスピーカ音圧ひずみの低減」, 電気学会マグネティックス研 資, MAG-95-188, pp.29-37 (1995)

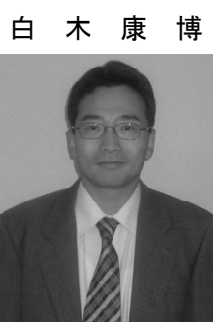

(正員） 1989 年 3 月岡山大·工・電気卒。 1991 年同大大学院修士課程了。同年三菱電機（株） 入社。以来, 電磁界解析を用いた電気・電子機 器の研究・開発に従事。現在, 同社先端技術総 合研究所勤務。電気学会会員。電子情報通信学 会会員。

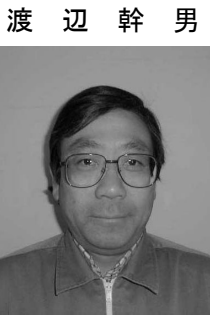

（非会員） 1981 年 3 月慶応義塾大 ・工・機械 卒。1983 年同大大学院修士課程了。同年三菱 電機（株）入社。以来, 宇宙機器, 電気摺動機 器, 磁気デバイス, 暖房機器, 電気給湯機に関 寸る研究・開発に従事。現在，同社群馬製作所 勤務。日本機械学会会員, 日本金属学会会員, 日本トライボロジー学会会員

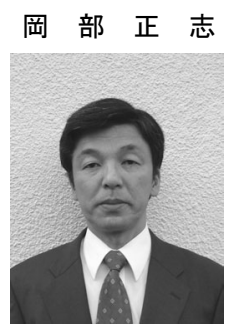

（正員） 1976 年 3 月岡山大 ・工・電気卒。 1978 年同大大学院修士課程了。同年三菱電機（株） 入社。以来, 電気 - 電子機器の開発に従事。現 在, 同社先端技術総合研究所勤務。電気学会会 員。

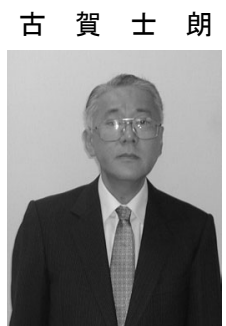

（非会員） 1978 年 3 月九州芸工大 芸術工学 部 音響設計科卒。同年三菱電機（株）郡山製 作所入社。家庭用ハイファイスピーカ, 業務用 スピーカ (放送用モニター等), 車載用純正ス ピーカ，携帯電話用音響部品の開発に従事，現 在，モバイルターミナル製作所勤務 